Post peer review version of Maja Zehfuss, "Writing war, against good conscience", Millennium: Journal of International Studies, vol. 33, no. 1 (2004), pp. 91-121. (ISSN 03058298)

\title{
Writing war, against good conscience
}

Maja Zehfuss

\begin{abstract}
Deployments abroad of the Federal Republic of Germany's armed forces are often contextualised in relation to the Second World War, but more concrete representations of war pose a difficult political problem. However, they are important in relation to the possibility of discussing war as an ethico-political issue. This article reads two novels, Gert Ledig's Die Stalinorgel and Martin Walser's Ein springender Brunnen, in order to engage in the particular and break up supposedly clear categories that inform thinking about war. It seeks to examine not the novels' political 'message', but more importantly the issues that may be raised by reading them in a way inspired by Jacques Derrida's work. The readings proposed here seek to resist the closure that would allow an easy conscience and instead explore ways in which the problem of war may be addressed as an ethico-political question.
\end{abstract}

Deployments abroad of the Federal Republic of Germany's (FRG) armed forces are often contextualised in relation to the Second World War. ${ }^{1}$ Most recently, in the debate over the deployment of 3,900 Bundeswehr troops to Afghanistan as part of Operation Enduring Freedom, Foreign Minister Joschka Fischer recalled the destruction that the war had brought for Germany, and which was still visible on the parliament building from which he spoke. ${ }^{2}$ Given the scale of devastation as a result of the Second World War-600.000 civilians died and 7.5 million were made homeless as a result of Allied air raids alone ${ }^{3}$ - such references are to be expected. The Second World War was not only memorable but also Germany's most recent military experience until the 1990s. During the Cold War, the invocation of the Second World War in relation to the question of military policy had come to be standardised

1 I am grateful to Ingo Leiß and Helmut Schmitz for sharing some of their expertise on German literature with me. I would also like to thank James Der Derian, Jenny Edkins, Hidemi Suganami, the audiences at my presentations at the 2002 ISA Convention, the 2002 CISA Conference and the Aberystwyth PostInternational Group, and the reviewers at Millennium for insightful comments on various versions of this text.

2 Deutscher Bundestag, Plenarprotokoll, 14/198, 08/11/01, 19293.

3 W.G. Sebald, Luftkrieg und Literatur. Mit einem Essay zu Alfred Andersch (Munich and Vienna: Carl Hanser Verlag, 1999), 11. This is in addition to an estimated 4.75 million killed and missing Wehrmacht troops. Volksploetz. Auszug aus der Geschichte, $4^{\text {th }}$ edition (Freiburg and Würzburg: Verlag Ploetz, 1984), 542. Although there are numerous problems in relation to estimating a figure for the total population at the time, this represents just under 10 per cent killed and over 10 per cent homeless, without taking into account the additional number of refugees from the East. 
into what was considered a key principle of FRG politics: 'Nie wieder Krieg' (never again war). Since the 1990s, however, the FRG has increasingly deployed its military abroad. The Second World War-and indeed the 'Nie wieder Krieg' principle-are still invoked, but now as the context within which every use of the military abroad becomes a question of responsibility. ${ }^{4}$ In 1994, then Foreign Minister Klaus Kinkel declared in reference to military operations abroad, that with respect to

responsibility for peace and human rights no one may stand aside, not even [the Germans]. Precisely because Germany has broken the peace in the past, it is morally-ethically obliged to participate in the defence of peace with all its power now. If there is one lesson from the period of National Socialism which is quite inescapable, then it is that unfortunately violence sometimes can just only be removed through counterviolence. ${ }^{5}$

Hans-Dietrich Genscher's complaint, after he had retired from his post as foreign minister, that in the government's argument 'new responsibility mean[t]: Bundeswehr deployments abroad $^{6}$ draws attention to just how much the question of responsibility and military policy had become intertwined. As a result, Germany is sometimes seen to have a particularly ethical approach to war, and Kinkel's intervention certainly suggests that this is what is intended.

Inspired by the work of Jacques Derrida, this article starts from the observation that this supposedly ethical approach to war actually effects a closure, and, moreover, one that makes it impossible to think about war as an ethico-political problem: thinking and deciding about war are turned into a question to be solved in the abstract. ${ }^{7}$ In other words, the choice between military intervention or refraining from using the military abroad is contextualised not within the particular situation the deployment would confront-for example civil war in Bosnia

$4 \quad$ For a detailed exploration of this issue, see Maja Zehfuss, Constructivism in International

Relations. The Politics of Reality (Cambridge: Cambridge University Press, 2002), ch. 3.

5 Deutscher Bundestag, Plenarprotokoll, 12/240, 22/07/94, 21166, all translations from the German are mine.

6 Quoted in 'Einsatz ins Ungewisse', DER SPIEGEL, 5/49, 30/01/95, 75.

7 This article develops insights gained by employing Derridean thought; it does not justify its use in the first place or evaluate it as against other academic approaches. Some may read the use of a Derridean approach in relation to the ethico-political question of war as an implicit critique of just war theory. Whilst it is the prerogative of readers to do so, a deconstruction of this theory is not proposed here; such an endeavour would necessarily involve a close reading of the texts of just war theory, a project that is well beyond the scope of this article. 
or human rights abuses in Kosovo-but rather within an understanding of the past, in particular the Second World War. This abstract approach makes possible, and indeed relies on, supposedly clear distinctions between perpetrators and victims, and good and bad war. This article argues that this closes off the space for ethico-political decisioning which must first of all recognise the lack of such clarity and acknowledge the aporia of making a decision. ${ }^{8}$

The article explores the particular in a bid to make closure more difficult. It moves away from seeing in each question about war merely an instance to which a general rule must be applied, for example a rule about the supposed responsibility that is seen to lie in the 'defence of the peace' by violent means. It takes seriously the references to the Second World War and, relying on Derrida's insistence that there is 'nothing outside of the text', ${ }^{9}$ do so by going beyond what is perhaps usually considered to be political discourse and present a reading of two novels, Gert Ledig's Die Stalinorgel and Martin Walser's Ein springender Brunnen. Literature, as the institution which 'gives in principle the power to say everything, to break free of the rules' ${ }^{\prime 10}$, may be seen to produce a significant problematisation of what at first appear to be clear categories-victim/perpetrator and good war/bad war. Crucially, taking seriously the problem of telling the truth about war involves not only a challenge to the underlying distinction between truth and fiction, but also supports the approach taken here in the first place: tackling the ethico-political problem of war through reading literature. Though the discussion may appear German-centric, the implications of this argument clearly go beyond German thinking about war. After all, the ethico-political question of war is one in which 'knowledge' fails to provide sufficient answers for all of us.

8 See Jacques Derrida, The Other Heading. Reflections on Today's Europe, trans. Pascale-Anne Brault and Michael B. Naas (Bloomington and Indianapolis: Indiana University Press, 1992), 41. Jacques Derrida, Of Grammatology, trans. Gayatri Chakravorty Spivak, corrected edition (Baltimore and London: The Johns Hopkins University Press, 1998), 158, emphasis in original.

10 Jacques Derrida, Acts of Literature, ed. Derek Attridge (London and New York: Routledge, 1992), 37 , emphasis in original. 


\section{Against good conscience}

Although deconstruction is now a well-established strategy in the study of international relations, ${ }^{11}$ it is perhaps useful to outline briefly the claims in relation to ethics on which my argument is based. ${ }^{12}$ Derrida rejects what he calls the 'the generality of ethics' which, he argues, 'incites to irresponsibility'. ${ }^{13}$ In his view, responsibility necessarily involves a transgression of such ethics. ${ }^{14}$ He argues that we do not act responsibly or ethically when we apply a rule, direction or programme; for this 'makes of action the applied consequence, the simple application of a knowledge or know-how. It makes of ethics and politics a technology ${ }^{15}$. Rather, for an ethical decision to be possible we have to experience an aporia: a "non-way", you cannot find your way: a-poria means that you cannot walk further, it's a blocked way, there is no way'. ${ }^{16}$ In other words, we find ourselves in an inescapable dilemma: a situation where the necessary decision is inevitably never fully ethical.

In The Gift of Death, Derrida discusses this problematic in relation to God's command that Abraham sacrifice his son Isaac. In such a situation it is impossible simply to make the ethically correct decision; rather there are 'moments in which the decision between just and unjust is never insured by a rule'. ${ }^{17}$ Derrida calls this the 'ordeal of the undecidable':

The undecidable . . . is not merely the oscillation between two significations or two contradictory and very determinate rules, each equally imperative... The undecidable is not merely the oscillation or the tension between two decisions; it is the experience of that which, though heterogeneous, foreign to the order of the calculable and the rule, is still obliged . . . to give itself up to the impossible decision, while taking account of law and rules. A decision that didn't go through the ordeal

11 Note, for instance, its use not only in major studies such as David Campbell, National Deconstruction. Violence, Identity, and Justice in Bosnia (Minneapolis and London: University of Minnesota Press, 1998) but also its inclusion in undergraduate textbooks. See, for example, Scott Burchill et al., Theories of International Relations, $2^{\text {nd }}$ edition (Basingstoke: Palgrave, 2001). On these issues also see the excellent introduction in Jenny Edkins, Poststructuralism and International Relations. Bringing the Political Back In (Boulder and London: Lynne Rienner Publishers, 1999), ch. 4.

13 Jacques Derrida, The Gift of Death, trans. David Wills (Chicago and London: The University of Chicago Press, 1995), 61.

14 See ibid.

15 Derrida, Other Heading, 45.

16 Jacques Derrida, Deconstruction Engaged. The Sydney Seminars, eds. Paul Patton and Terry Smith (Sydney: Power Publications, 2001), 63, emphasis in original.

17 Jacques Derrida, 'Force de Loi: Le "Fondement Mystique de l'Autorité"'/'Force of Law: The "Mystical Foundation of Authority"', trans. Mary Quaintance, Cardozo Law Review 11 (1990): 947. 
of the undecidable would not be a free decision, it would only be the programmable application or unfolding of a calculable process. ${ }^{18}$

Crucially, the decision must be made-it cannot be simply avoided. However, the undecidable remains caught in every decision. ${ }^{19}$ As a result, there is never a moment that allows us to look back at the decision in good conscience and feel certain about its ethicality.

Thus ethics becomes both possible and necessary when there is more at stake than the application of a rule. As Derrida puts it, 'I will even venture to say that ethics, politics, and responsibility, if there are any, will only ever have begun with the experience and experiment of aporia'. ${ }^{20}$ Moreover,

To have at one's disposal, already in advance, the generality of a rule [règle] as a solution to the antinomy ... to have it at one's disposal as a given potency or science, as a knowledge and a power that would precede, in order to settle [régler] it, the singularity of each decision, each judgment, each experience of responsibility, to treat each of these as if they were a case-this would be the surest, the most reassuring definition of responsibility as irresponsibility, of ethics confused with juridical calculation, of a politics organized within techno-science. ${ }^{21}$

This means that the situation of the aporia is, on the one hand, one of despair but provides, on the other, the opportunity that makes possible an ethico-political decision. ${ }^{22}$ It is precisely when all we know is that we do not know what to do that we can-and must-make an ethico-political decision. Such decisions thus arise in situations that are in some way 'beyond' knowledge. The belief that knowledge or rules are the secure basis for ethical decisions can never be more than a dangerous illusion that leads to nothing but 'good conscience $^{, 23}$, something that it is imperative to avoid. ${ }^{24}$

\section{Writing the war}

The Germans are often seen as obsessed with their past, that is, with the history of the Third Reich and the Second World War, and references to the war in discussions about the military

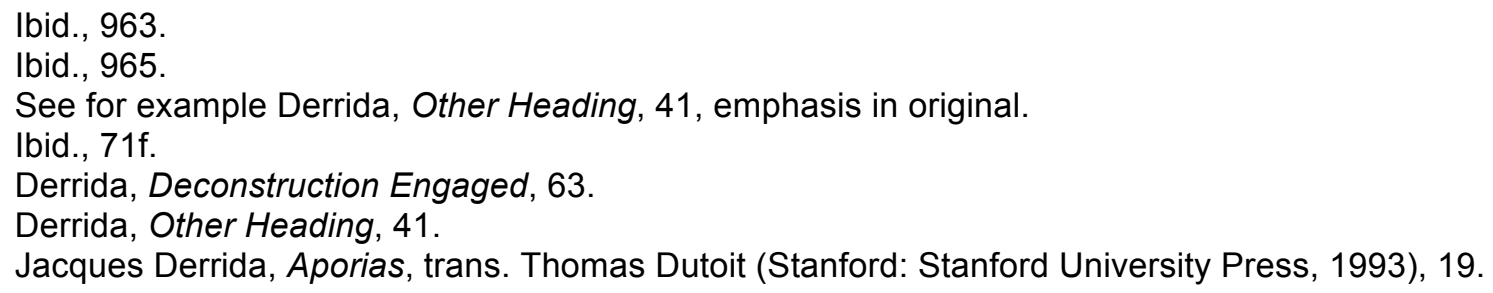


instrument might confirm such a view. Before proceeding to read the two novels, it is therefore useful to briefly probe the context of memories of the Second World War in the FRG. In Wages of Guilt. Memories of War in Germany and Japan, lan Buruma claims that the 'German war was not only remembered on television, on the radio, in community halls, schools and museums; it was actively worked on, labored, rehearsed. One sometimes got the impression, especially in Berlin, that German memory was like a massive tongue seeking out, over and over, a sore tooth'. ${ }^{25}$ However, this supposedly obsessive memory of the war foregrounds recollection of the Holocaust rather than experiences in war situations such as combat or air raids. In fact, Buruma explains that he focuses on the war against the Jews 'since it was that parallel war, rather than, say, the U-boat battles in the Atlantic, or even the battle of Stalingrad, that left the most sensitive scar on the collective memory of (West) Germany, ${ }^{26}$ Thus his book is less about the memory of the Second World War, as its title suggests, than about the memory of the Holocaust. Indeed, Elizabeth Domansky diagnoses a 'displacement of World War II by the Holocaust' in German politics of memory from the late 1960s onwards. ${ }^{27}$ In other words, though Germans today might be obsessed with their past, it is less clear that the Second World War plays a crucial role in this.

However, In War Stories. The Search for a Usable Past in the Federal Republic of Germany Robert G. Moeller explores the memorialisation of the Second World War in the immediate postwar years and its political significance. ${ }^{28}$ He argues that '[o]ne of the most powerful integrative myths of the 1950s emphasized not German well-being but German suffering; it stressed that Germany was a nation of victims, an imagined community defined by the experience of loss and displacement during the Second World War'. ${ }^{29}$ Furthermore, according to Moeller, 'what Germans recalled of their wartime experiences in the 1970s,

\footnotetext{
25 Ian Buruma, Wages of Guilt. Memories of War in Germany and Japan (London: Vintage, 1995), 8.

27 Elisabeth Domansky, 'A Lost War. World War II in Postwar German Memory', in Thinking about the Holocaust. After Half a Century, ed. Alvin H. Rosenfeld (Bloomington and Indianapolis: Indiana University Press, 1997), 246 and 251-258.

28 Robert G. Moeller, War Stories. The Search for a Usable Past in the Federal Republic of Germany (Berkeley, Los Angeles and London: University of California Press, 2001). Ibid., 6.
} 
1980s, and 1990s was necessarily filtered through the forms of public memory that emerged in the Federal Republic's early history'. ${ }^{30}$ At the same time war memories increasingly came to be associated with an unpalatable rightwing politics intent on exculpating the Wehrmacht and regaining eastern territories. What came to be known as the Historikerstreit (Historians' Debate) did little to dispel this idea. In the 1980s prominent historians and other intellectuals debated the role of memories of the Third Reich in relation to the identity of the (West) German nation at the time. ${ }^{31}$ Of most significance in the context of my argument is that, as Helmut Peitsch notes, the 'main protagonists of the right in the Historians' Debate of 1985 concentrated on ... the innocent German soldier on the Eastern Front who suffered in order to protect women and children against the threat of Asiatic barbarity'. ${ }^{32}$

Thus, not least because of such past debates, discussing, indeed even mentioning, Germans' suffering due to the war always runs the risk of being seen as part of an effort to relativise the Holocaust: 'The Germans suffered, too; they were victims of the Third Reich, as well'. There is thus a suspicion that remembering the war can only ever serve a rightwing cause. In this view, war memories would confer the status of 'victim' on Germans-for example in relation to the Allied bombing raids against German cities-and would therefore in some way be seen to exculpate the Germans. Yet since the mid-1990s there has been a growing interest in the war across society. There are now numerous publications dealing with the expulsion of Germans from eastern territories and the air war. ${ }^{33}$ Inevitably, there is concern that this interest reflects a dangerous new German self-conception as victims, ${ }^{34}$ a

\section{Ibid., 174.}

See Forever under the Shadow of Hitler? Original Documents of the Historikerstreit, the Controversy Concerning the Singularity of the Holocaust, trans. James Knowlton and Truett Cates, (New Jersey: Humanities Press, 1993).

32 Helmut Peitsch, 'Discovering a Taboo: The Nazi Past in Literary-Political Discourse 1958-67', in Taboos in German Literature, ed. David Jackson (Providence, RI and Oxford: Berghahn Books, 1996), 137.

33 See, for example, Jörg Friedrich, Der Brand. Deutschland und der Bombenkrieg 1940-1945 (München: Propyläen, 2002); Lothar Kettenacker, ed., Ein Volk von Opfern? Die neue Debatte um den Bombenkrieg 1940-45 (Berlin: Rowohlt, 2003); 'Deutschland nach dem Krieg 1945-1955' special issue, GeoEpoche 9 (2002).

34 See Kettenacker, Ein Volk von Opfern?; Michael Schaper, 'Ein Volk von Opfern', in 'Deutschland nach dem Krieg 1945-1955', 3. 
concern that, significantly, is also raised in regard to literary representations of the war. ${ }^{35}$ Thus, exploring representations of the Second World War in the context of current military policy inevitably touches on controversial issues.

Public debate clearly has found the issue of war memories problematic. If literature is, as Derrida suggests, the institution that 'gives in principle the power to say everything, to break free of the rules', one might expect a less inhibited approach to memories of the war in novels. However, there seems to be no Second World War equivalent to Erich Maria Remarque's famous First World War novel Im Westen nichts Neues (All Quiet on the Western Front). ${ }^{36}$ In Wages of Guilt, Buruma suggests that Günter Grass's novel Die Blechtrommel (The Tin Drum) may be 'the world's most famous fictional chronicle of World War II'. ${ }^{37}$ Strangely, though, for a chronicle of the war, the war itself hardly appears in the novel. This is not to say that it does not offer any insight on the Second World War or indeed that this engagement with the war is in some way faulty. Jochen Pfeifer, in his study of German war novels published between 1945 and 1960, in fact argues that some novels that address the war only obliquely have more interesting things to say about its political and historical context than do war novels. ${ }^{38}$ Still, it is perhaps worth noting that 'the world's most famous chronicle of World War II' contains no description of combat, and only limited reference to the air war and civilian coping strategies in response to the war. In this context, W.G. Sebald's 1997 assertion, with specific reference to air raids on German cities, that German literature had not appropriately engaged with the war is perhaps understandable, ${ }^{39}$ there may indeed be a wider argument to be made about the Second World War and German literature.

35 See Helmut Schmitz, On Their Own Terms. The Legacy of National Socialism in Post-1990 German Fiction (Birmingham: University of Birmingham Press: forthcoming 2004), ch. 9. Schmitz, however, does not entirely subscribe to this view.

36 Erich Maria Remarque, Im Westen nichts Neues, ed. Brian Murdoch (London: Routledge, 1984). See also Domansky, 'A Lost War', $241 \mathrm{f}$.

37 Buruma, Wages of Guilt, 292.

38 His example is Thomas Mann's Doktor Faustus. Jochen Pfeifer, Der deutsche Kriegsroman 1945-1960. Ein Versuch zur Vermittlung von Literatur und Sozialgeschichte (Königstein/Ts.: Scriptor, 1981), 150.

39 Sebald, Luftkrieg und Literatur. See Volker Hage, Zeugen der Zerstörung. Die Literaten und der Luftkrieg. Essays und Gespräche (Frankfurt am Main: S. Fischer Verlag, 2003) for a response to Sebald's arguments. 
Despite this initial impression of a scarcity of representations, German literature has dealt with the war repeatedly. ${ }^{40}$ Most of this literature has, however, fallen out of favour and certainly been discounted in relation to questions of politics due to its alleged political myopia. Early postwar German literature, often referred to as Trümmerliteratur (literature of the rubble) ${ }^{41}$ tended to draw the reader into solidarity with the common soldier. The 'enemy' in this set-up is the military and/or political leadership. Heinrich Böll's novel Wo warst du, Adam? (Where were you, Adam?), ${ }^{42}$ which first appeared in 1949 , has been criticised, along with much of the Trümmerliteratur, for subscribing to the fiction that the German common soldier was essentially good but abused by his superiors. ${ }^{43}$ Wo warst $d u$, Adam? could be read as a demand for individual accountability, and yet the answer, 'I was in the World War', can also be seen as an escape from responsibility. Ernestine Schlant certainly argues that this answer, given in the epitaph to the book, 'takes refuge in an alibi that seemingly submerges the individual in the enormity of the world war'. ${ }^{44}$ Some of this literature has also been called Obergefreitenliteratur (literature of the lance-corporals) with reference to the military rank of its main characters. The focus on the common soldier is seen as a way of evading a discussion of the political and historical context of the war. ${ }^{45}$ The lance-corporals cope with war as it presents itself to them; they do not shape the war. Their low rank means that they could, or even had to, take a 'whether right or wrong, it is my country' attitude. They were, as the conservative historians in the Historikerstreit were seen to assert on behalf of the Wehrmacht, merely defending their fatherland; they did not have any input into the

40 See Hage, Zeugen der Zerstörung; Alan Bance, 'Germany', in: Holger Klein (ed.), with John Flower and Eric Homberger, The Second World War in Fiction, eds. Holger Klein, John Flower and Eric Homberger (London and Basingstoke: Macmillan, 1984), 88-130; Pfeifer, Der deutsche Kriegsroman; Paul Ingendaay, 'Rede des sterbenden Soldaten über seinen Diktator', Frankfurter Allgemeine Zeitung, 12/04/97, 31; Schmitz, On Their Own Terms, section 4.

41 On the Trümmerliteratur see, for example, Ernestine Schlant, The Language of Silence. West German Literature and the Holocaust (New York and London: Routledge, 1999), 23; Reiko Tachibana, Narrative as Counter-Memory. A Half-Century of Postwar Writing in Germany and Japan (Albany, NY: State University of New York Press, 1998), 7, 32 and 83.

42 Heinrich Böll, Wo warst du Adam? und Erzählungen (Cologne: Friedrich Middelhauve Verlag, 1967).

43 Schlant, Language of Silence, 30. See also Sebald, Luftkrieg und Literatur, 17f; Tachibana, Narrative as Counter-Memory, 84. For an ambiguous view see Alan Bance, 'Heinrich Böll's "Wo warst du, Adam?": National Identity and German War Writing - Reunification as the Return of the Repressed?', Forum for Modern Language Studies xxix, 4 (1993).

44 Schlant, The Language of Silence, 30.

45 Pfeifer, Der deutsche Kriegsroman, esp. 60f, 92 and 111. 
objectionable policies that their country was pursuing. Thus, the Obergefreitenliteratur often simply avoids the issue of Nazism. ${ }^{46}$ Some of this literature is therefore regarded as an inappropriate apology for the German soldier.

The two novels read in this article are no different: they focus on the war experience of people who are depicted as unable to shape the war itself. In other words, they do exactly what critics see as at least dangerously close to construing Germans as the 'real' victims of the war. The question of National-Socialism as the political context of literary representations of the Second World War is certainly important; it has been explored extensively. ${ }^{47}$ However, this question is here deliberately left to one side in order to focus specifically on war and to destabilise categories that seem to be taken as given. In as much as politics is about 'a certain type of non-"natural" relationship to others'48, the exposure of seemingly 'natural' categories as problematic, and indeed impossible, through reading these novels constitutes a political intervention, particularly because of the stakes invested in such categories in relation to the question of war.

\section{Recreating immediacy: Gert Ledig's Die Stalinorgel}

Gert Ledig experienced the war both as a soldier and-after having been wounded-as a civilian. Die Stalinorgel, ${ }^{49}$ originally published in 1955 , was followed a year later by another novel, Vergeltung (Retaliation); unlike the Trümmerliteratur, both novels offer no positive gloss on anything about the war. The former, an account of the war on the Eastern front, was popular at the time, whilst the latter, a depiction of ninety minutes during an air raid, was considered too gruesome. ${ }^{50}$ The virtual disappearance of both novels until their recent

$46 \quad$ Ibid., 135.

47 See, for example, Schlant, The Language of Silence; Pfeifer, Der deutsche Kriegsroman; Hans Wagener, ed., Gegenwartsliteratur und Drittes Reich. Deutsche Autoren in der Auseinandersetzung mit der Vergangenheit (Stuttgart: Reclam, 1977).

48 Jacques Derrida, Limited Inc (Evanston: Northwestern University Press, 1988), 136.

49 'Stalinorgel'-literally 'Stalin's organ'- -is an expression used by German soldiers to refer to the rocket launchers BM 8 and BM 30 (also known as 'Katjuscha') used by the Red Army in the Second World War because of the loud, howling noise they produced. I am grateful to Ken Booth for advice on the colloquial expression in English.

50 Florian Radvan, 'Nachwort', in Die Stalinorgel, Gert Ledig (Frankfurt am Main: Suhrkamp Verlag, 2000), 203-229; Volker Hage, 'Die Angst muß im Genick sitzen', DER SPIEGEL, 1, 04/01/99, 160; Sebald, Luftkrieg und Literatur, $100 f$. 
republication ${ }^{51}$ is perhaps not surprising. Those who had lost loved ones to Allied bombing were unlikely to want to read a terrifyingly detailed account of their suffering. The description in Vergeltung of how a young girl, trapped underneath the rubble together with a man, is raped and, after he commits suicide, left alone to die with his body next to her, could be considered quite unsettling. ${ }^{52}$

Die Stalinorgel is a complex, but equally harrowing account of 48 hours of battle over a single hill close to Leningrad, which however found more favour with the reading public and the critics. ${ }^{53}$ Ledig's account of soldiers' experiences is different from those mentioned so far in that it offers no redeeming features to the war experience. This is not the story of a cruel world which is confronted through a sense of duty or with heroism. There is 'no mercy', not even for the dead, in Ledig's account. ${ }^{54}$ War is a senseless hell, 'pure madness', an 'absurd spectacle of horror'. ${ }^{55}$ Die Stalinorgel opens with the image of a lance-corporal, stuck upside down in a tree, both hands shot off and dead. ${ }^{56}$ Half an hour later, when the tree is felled by machine gun fire, the lance-corporal also loses a foot. 'When he fell on the ground, he was only half a man. ${ }^{57}$ A minute later, what is left of him is flattened by a tank. An explosion throws up the mass of scraps of uniform, flesh and blood. 'Then finally the lance-corporal was left alone. ${ }^{58}$ As there is no one alive to report his death, the lance-corporal counts as missing.

We encounter the lance-corporal only when he is already dead. Like most characters in the novel, he is never given a name. They are referred to by their military rank only, which, given that more than one major or sergeant appears, makes it quite difficult to follow them as individuals. The storyline jumps from different positions on the German front, as well as into

\footnotetext{
$51 \quad$ Radvan, 'Nachwort', 203 and 227f; Volker Hage, 'Die Angst muß im Genick sitzen', DER SPIEGEL, 1, 04/01/99, 160.

52 Gert Ledig, Vergeltung (Frankfurt am Main: Suhrkamp Verlag 1999), 96-99, 121f, 131, 142-144, $157-159$ and $174 \mathrm{f}$.

53 Radvan, 'Nachwort', 206f; Sebald, Luftkrieg und Literatur, 100.

54 Volker Hage, 'Die Angst muß im Genick sitzen', DER SPIEGEL, 1, 04/01/99, 160.

55 Ibid., 162.

$56 \quad$ Ledig, Die Stalinorgel, 7.

57 Ibid.

58 lbid., 8.
} 
the Russian trenches. This breaking up of the story seems to reflect the scramble of the senseless battle over the hill, in which finally no one wins. This, and the relentless realism of description, systematically undermines any simplistic identification with the soldiers. Any act that could potentially be described as altruistic or even heroic is contextualised within an account of confusion, egotism, base motives and appalling sanitary conditions. It is not just that no hero walks off into the sunset; it is that there are only characters in this novel who have already been brutalised to such an extent by the war that, even where they might commit an act of heroism, it appears futile, if not naive; it certainly would not inspire admiration.

Many elements of Ledig's novel are familiar to us from other war novels: a commanding officer issuing a senseless command and later coming to regret it; small acts of defiance against superior officers ('No soldier may refuse an order, but he may forget about it' ${ }^{59}$ ); desertion in the heat of battle; a fanatic insisting on shooting one particular deserter as a warning to others whilst hundreds retreat against orders; amputations under horrific conditions; brutality against captured enemies; orders which make no sense once they reach the front; ambiguous orders and superiors trying to shift responsibility to those they command; appalling conditions; an act of heroism; and death, death and death again. However, unlike in novels like Im Westen nichts Neues, or indeed Wo warst du, Adam?, the point does not seem to be to draw the reader into sympathy with the common soldier in any straightforward way.

The description of grimy, dusty, hairy men vegetating in a hole in the ground, waiting to fulfil an order that will almost certainly result in their death, trying to numb themselves with alcohol, defecating onto a spade or into empty tins, so that they need not risk their lives by crawling out of the hole ${ }^{60}$ undercuts any notion of underdog heroes. Equally, when engineer Meller-one of the few characters with a name-blows himself up with two hand grenades in a bid to create an opening for his unit which has been surrounded, he does so only because

\footnotetext{
59 Ibid., 29.

60 Ibid., 13.
} 
he has already received a fatal wound to the stomach. ${ }^{61}$ Meller's death is described in gruesome detail and his commanding officer finds himself unable to write the usual letter to the family about the 'shot in the chest and painless death'. ${ }^{62}$

Representations of war are always fraught with difficulties, not least the risk of trivialising the bloodshed and/or heroicising war. Die Stalinorgel is clearly designed to re-create the carnage without representing the soldiers as heroes. Three points seem worth noting here. Firstly, Die Stalinorgel lacks characters who could take readers through the confusion of the battle and allow them to identify with someone. Although certain characters appear time and again, they neither invite such identification nor do they reduce the sense of unmitigated mayhem going on around them. Secondly, there is no difference in the portrayal of Russian and German soldiers. In fact, both a captured Russian and a captured German observe that those holding them are much like their fellow soldiers; all have the same desire for 'a little food, some warmth, no suffering any more'.63 However, this is not to conjure up some sentimental notion of a common humanity. The Germans are also described as 'animals' by a Russian, ${ }^{64}$ and both are observed in acts of brutality against enemy soldiers. ${ }^{65}$ This evenhanded treatment, which nevertheless offers no hope, is crucial in terms of the standard objection against German war memories as portraying the Germans as victims of the Third Reich, as counting up German suffering against the suffering of the victims of the Germans. Ledig's novel is not about German soldiers, and therefore arguably of little use to any revisionist reconstruction of German identity; it is about the senseless hell of war.

Finally, the novel is such a horrific read not just because of all the gruesome detail, but because of its complete denial of hope. Already the opening scene is one of uncontrolled mayhem in which it is impossible, and would certainly be irrational, to have the slightest concern for others. Throughout the novel there is no comradeship under fire to take the edge off the horror conjured up in the painstakingly detailed description. Towards the end of the

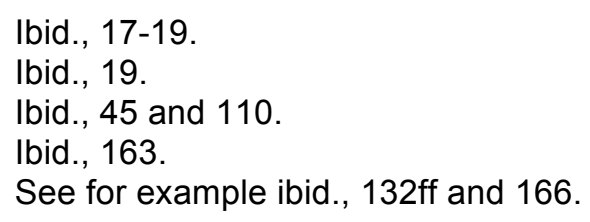


book, the major, looking at his men, remembers a time when there might still have been something like comradeship, earlier in the war. But now what he sees is a 'bunch of lonely men. Already they envy one another, coveting what little tobacco remains in their pockets. A crust of bread, hard as a rock. A handful of cartridges, picked up from the dirt'. ${ }^{6}$ Everyone only wants to survive for themselves. As the captain thought much earlier on: 'He wanted to live, like they all wanted to live. He had come to the conviction that it was better not to be a hero and instead to stay alive'. ${ }^{67}$

Thus, Die Stalinorgel, though certainly a war novel, is designed to be an anti-war novel. Yet where Remarque could bluntly state that this 'book is meant to be neither an accusation nor a confession. It is only the attempt to report about a generation, who was destroyed by the war-even if it escaped its shells'68, depicting the 'German' experience of the Second World War in literature is more complicated. Since the generation who were soldiers in the later war are not seen as having been innocent in the same way, remembering their destruction is a politically more complex task. Ledig has one soldier state that 'we have all been betrayed'. ${ }^{69}$ However, unlike Remarque, Ledig does not seem to be interested in generating sympathy for those who had to go through the hell of war. This novel is less about the soldiers' plight than, more fundamentally, about the futility and gruesomeness of war. As the major observes, he 'wanted to go to hell. And here it was. Complete with everything a sick mind could imagine'. ${ }^{70}$ The 'betrayal' is thus both more ambiguous and more complete than that which Remarque may be describing. In the final scene of the book, the survivors of the battle attend a funeral. The army chaplain speaks of the comfort coming from the knowledge of salvation after death. The sergeant and the major leave during the funeral, discussing their 'secret' hope that this is true. As the major notes: 'It doesn't bear thinking about that we may be cheated even out of that'. ${ }^{71}$

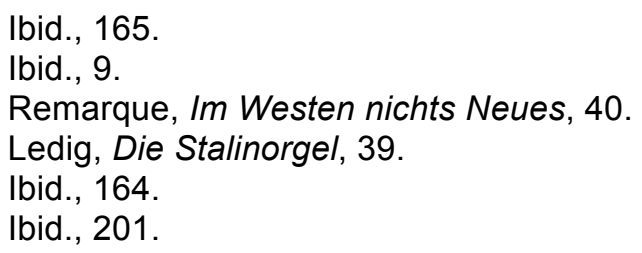


Ledig's bleak account of war was 'rediscovered' in the late 1990s-apparently in response to a lecture series Sebald gave about the failure in German literature to address the experience of the bombing of German cities $^{72}$-and republished in 2000 . Thus it is part of a series of recent republications and publications that attest to a new interest in the war, notably at a time when the German military is involved in combat again. Ledig's aim seems to be to tell how it 'really was', to re-create the war experience for those who were not there. Ledig's effort at writing again late in his life-about the war in Bosnia-failed. He said that it 'didn't work. Too much distance. Fear has to be sitting on your own neck, you have to know that exactly'. ${ }^{73}$ Ledig, in other words, appears to have been motivated by a desire to reveal the truth about war; his writing is seen to imply 'a claim to truth'. ${ }^{74}$ It is driven by what Reiko Tachibana calls, in relation to early writing about Hiroshima and the Third Reich, the 'recreation of immediacy'. ${ }^{75}$ Ledig, who had experienced the horror of battle himself wanted to bear witness. He wanted to tell it how it was. It is interesting to note that such 'bearing witness' should turn to fiction, which is often construed to be the opposite of truth. War, apparently, cannot be represented simply 'as it was'; fiction is in some way necessary to approach what may be considered the 'truth', a view that appears to be confirmed by the reading public's recent interest in fiction about war. The disorientation created by Ledig's narrative strategy perhaps might tell us more about what 'it was like' than a detailed historical account which would perhaps impose a meaning that was not available to those involved. Thus, Ledig's depiction raises the question of what it means to tell the truth about war, an issue I will explore further in the last section of this article. This question also appears in a very different guise in Walser's novel, to which I now turn.

\section{Impossible authenticity: Martin Walser's Ein springender Brunnen}

Martin Walser, born in 1927, and one of Germany's most influential novelists, announced in the 1980s that he would 'demand of himself' a novel about his own experiences in the

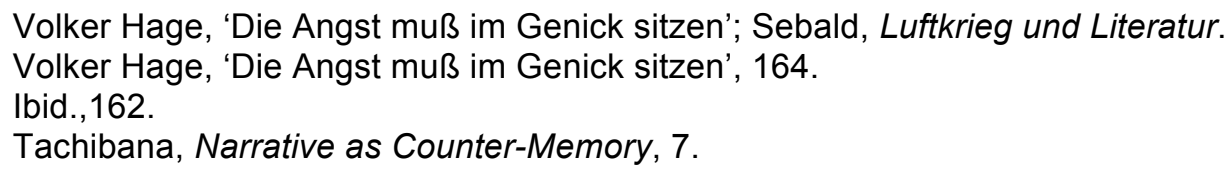


Second World War. ${ }^{76}$ Ein springender Brunnen (A Gushing Fountain), ${ }^{77}$ published in 1998 , is the result of this determination. The novel opens with a chapter on the 'Past as Present', as does each of the three parts of the book: 'As long as something is, it is not what it will have been. When something is over, one is no longer the one to whom it happened. . . Although the past, when it was the present, did not exist, it now imposes itself, as if it had existed in the way in which it imposes itself now' ${ }^{78}$ In the collective past one can walk about as if in a museum, but not so in one's own past. Of our own past, we 'only have what it reveals' ${ }^{79}$ As Walser puts it, '[w]e survive not as those who we were, but as those who we have become after we have been. When it is over. For it is still, even if over. Now is there more past or more present in being over? ${ }^{80}$ Walser is obviously deeply interested in memory, and its relation to the present.

Ein springender Brunnen tells of the childhood of Johann, who is five years old in 1932 when the novel starts. I am here most interested in the third and final part of the book, which deals with the period of Autumn 1944 until Summer 1945. It is the first time the war becomes relevant to Johann and indeed to Wasserburg, the small town on Lake Constance where the book is set. Johann is seventeen, writes poetry and is constantly thinking about women and, having been brought up by a devoutly Catholic mother, in a rather roundabout way about sex, and about his manhood. The military and war, as the ultimate sites for virility, are hugely important in his perception of himself as growing up, as following in the footsteps of his elder brother Josef. Johann has already taken over crucial parts of the mother's business since Josef has been drafted, first to the Reichsarbeitsdienst, ${ }^{81}$ and then into the military.

The second chapter of part three of the book is told as Johann's stream of consciousness while he is harvesting apples. He starts by contemplating that as he is now

\footnotetext{
76 Volker Hage, 'Königssohn von Wasserburg', DER SPIEGEL, 31, 27/07/98, 148.

77 Ein springender Brunnen is a reference to Nietzsche's phrase 'My soul is a gushing fountain' in Zarathustra. Friedrich Nietzsche, Also sprach Zarathustra. Ein Buch für Alle und Keinen (Berlin: Walter de Gruyter \& Co, 1968), 132.

78 Martin Walser, Ein springender Brunnen (Frankfurt am Main: Suhrkamp, 2000), 9.

79 lbid., 9.

80 Ibid., 15.

81 A form of pre-military service in the Third Reich.
} 
able to carry a much bigger sack of apples on the ladder than he had been when he was younger, he is no longer able to do this job barefoot. Therefore, he thinks about his footwear. $\mathrm{He}$ is wearing the boots of the Reichsarbeitsdienst, but is hoping soon to exchange them for those of the Gebirgsjäger (mountain troops). ${ }^{82} \mathrm{He}$ is embarrassed about his Navy uniform. He finds it 'exaggerated', 'almost ridiculous'. ${ }^{83}$ When he joins the proper military he never wants to be in the Navy, never wants to have a cap without a shield. In view of the awful uniform, he doesn't comprehend how anyone could volunteer for the Navy at all. ${ }^{84}$ Johann is also critical of his brother's uniform. The cap of the Gebirgsjäger, which he would get, is 'smarter' ${ }^{85}$

Johann's interest in being able to wear the best uniform combines with his desire to be seen to be courageous. When his friend Adolf volunteers for the Flak, Johann finds the decision incomprehensible, but does not dare to ask for the reasons. In Johann's view, those 'who volunteered for the Flak thereby confessed that they did not want to go to the front, that others should go to the front. Especially if Johann had not wanted to go to the front, he would never have admitted to that by signing up for the Flak'. ${ }^{86}$ Johann is desperate to join the military and prove himself at the front. ${ }^{87} \mathrm{He}$ writes to his brother Josef at the Eastern front that he is hoping for his call-up to arrive soon. ${ }^{88}$ Finally, in December 1944 , after Josef has already been killed in action, ${ }^{89}$ Johann reports for duty in Garmisch. He looks forward to skiing, walking in the mountains, long evenings in mountain cabins, lots of singing and, best of all, 'the most beautiful of all possible uniforms'. ${ }^{90}$ He thinks of Friedrich Nietzsche's Zarathustra $^{91}$ and, as he is skiing through heavy snowfall, Johann decides that nothing he is learning in the mountains could ever be relevant to war. ${ }^{92}$ The incredible beauty of the

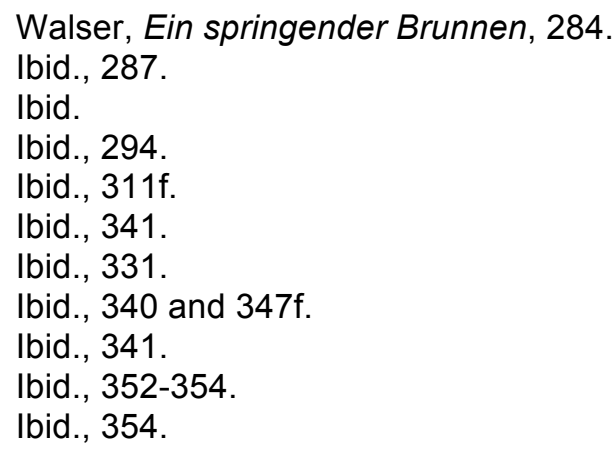


landscape in the Alps makes it impossible to think that what he is doing is training for war. In any event, Johann never sees any action, as the war is over before his training is complete.

Thus, only through Johann's reflection on hearsay, or his reports of what he has been told by specific people, do we hear of any problematic aspects of the German armed forces' conduct. His brother's letters, another source of information on the war, unsurprisingly contain no such descriptions. ${ }^{93}$ In a POW camp, a lance-corporal confesses to Johann that as part of the SA he has taken part in the persecution of Jews; he has to keep imitating dogs' barks at night to keep himself from thinking whether he will have to pay for it. Johann does not seem to understand quite what this man, who breaks down whimpering, is telling him. He finds the man's smelly feet more repulsive than what he has told him. ${ }^{94}$ On the topic of SS atrocities, Johann is more certain: 'There were rumours that the SS did not take prisoners in the East. Johann took this to be propaganda, because it had to be just unimaginable to still shoot someone who has given himself up to you as a prisoner. . . To consider something like this possible was despicable'. ${ }^{95}$ Johann had, however, never been a fan of Nazism. Much to the contrary. He explains his own ability to be involved with the ideology, such as in his oath for the military, by saying that he merely had to '[r]epeat and say out loud and promise what was none of his business'. ${ }^{96}$ It was just another formula, like voicing a resolution, as a Catholic, in confession.

Johann's story also includes references to the effect the war was having on civilian life, if only in a mediated way, not least because in his region they only dropped bombs on their way back, that they had not been able to get rid of over the cities. ${ }^{97}$ He observes that there are a lot of women in town, each with two to four children. 'All city folk. Bombed out of their homes. Refugees'. ${ }^{98}$ One family is now quartered on his mother's property, in the former
lbid., 328-331.
lbid., $357 f$.
lbid., 345.
Ibid., 351.
Ibid., 290.
Ibid., 296. 
stables. ${ }^{99}$ Nevertheless, Ein springender Brunnen is not, despite Walser's announcement that he would write about his own experiences in the Second World War, a book primarily about the war. It is rather a novel about growing up, where the growing up is done under peculiar political circumstances which in the end also involve war. And yet it is interesting as a depiction of the Second World War by a German. In a country where military matters were until recently regarded with the greatest of suspicion by all but the far right, speaking about a young boy signing up in the Second World War because he fancied wearing a particular uniform and expected that doing so would confer manhood upon him is, in my view, anything but politically correct. Johann, on his way back from Garmisch to Wasserburg, is even robbed of his gun, cigarettes and watch by ex-concentration camp inmates, still wearing the camp uniform marked as 'homosexual' by a pink triangle. ${ }^{100}$ This scene in particular is left bizarrely uncontextualised and no light is shed on why it is there. Presumably, this lack of political contextualisation is, in Walser's view, due to what he calls the 'Urgesetz des Erzählens', the most basic rule about telling a story: perspectivity [Perspektivität], ${ }^{101}$ or the freedom to choose a perspective and resist the use of any information that would not be 'visible' from that perspective.

Despite his belief in this basic rule, the text betrays Walser's concern about how his depiction of this period would be taken. His musings on the 'past as present' at the beginning of the third part of the novel suggest as much. He writes that those 'who most ardently take trouble over the past, are most in danger of taking that which they have created to be what they have been looking for. We cannot admit that there is nothing but the present. For it does not really exist either'. ${ }^{102}$ Thus, whatever he may be writing about this past, it will always be more about the present, insofar as this present exists. Of course, some like to slip out of their past in order to present a more beneficial past, but what Walser is particularly concerned about is control over the past. 'In reality dealing with the past becomes more and

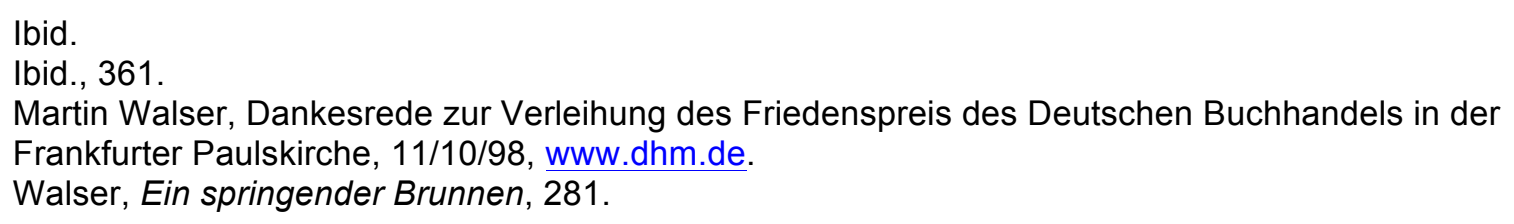


more standardised decade after decade. The more standardised this dealing, the more what is presented as past is a product of the present'. ${ }^{103}$ Thus the past becomes a fund from which one may pick and choose as one wishes. 'A past which is completely reconstructed [erschlossen], investigated, sanitised, sanctioned, totally fit for the present. Ethically and politically corrected through and through'. ${ }^{104}$ And finally, '[w]hatever may have been our past, we have liberated ourselves from everything which was such then that we do not want it any more now'. ${ }^{105}$ It is the notion of Vergangenheitsbewältigung (coming to terms with the past) that Walser takes issue with, and if his story about Johann considering the mountain troops' uniform sexy or being robbed by ex-concentration camp inmates interferes with the dominant discourse on the past, this is fine by him. Thus he would seem to endorse literature's function as counter-memory-in other words, as a necessary opposition to the reassuring stability of traditional history-which Tachibana stresses. ${ }^{106}$ Walser claims a right to his memory, however subjective and indeed epistemologically insecure, and however much in tension with what is, in the dominant political discourse, considered an appropriate memory.

It is crucial to note that Walser's musings on 'the past as present' at the same time undermine any simplistic notion of revealing the truth about the past or bearing witness. Ledig's turn to fiction in order to show what war was like already betrays the impossibility of simply telling it as it was. Ledig's ruptured plot works against a singular narrative and thus his book gives no simple answer to the question of what happened, what it was like. This destabilises the possibility of the monolithic or formulaic memory often called upon when referring to the 'experience' of the Second World War merely to underline the 'never again' mantra. The assault on this attitude in Walser's text is subtler, but at the same time more fundamental. The issue of memory, the way in which the present always already interferes with any telling of the past, is foregrounded. Thus, the idea of a 'truth' about the past is a fiction, because this truth is itself subject to change in time. This truth itself has a history. Or

\footnotetext{
103 Ibid., 282.

104 Ibid.

105 Ibid., $282 \mathrm{f}$.

106 Tachibana, Narrative as Counter-Memory, 1.
} 
as Walser puts it, we cannot recall what was as we experienced it then because we are no longer who we were. It is this reflection on time, truth and memory that makes Walser's novel relevant beyond the specific story it may be telling. Taking seriously this aspect of the novel also makes it necessary to go beyond an interpretation that focuses on how Walser opposes public forms of memory against private conscience in a bid to value the latter over the former. ${ }^{107}$ This may be what Walser as a person intended, though we don't know; but it is not all his text tells us.

\section{Breaking up the categories}

Depictions of the Second World War by German writers are invariably interpreted in relation to politics. As mentioned above, Pfeifer has criticised novels about this war for excluding the political context. More specifically, Ledig's strategy of rendering vivid the brutality of the war, according to Pfeifer, limits itself to the trivial message that war is nasty, thereby failing to understand the particular problem of the Second World War. ${ }^{108}$ Thus, this literature is considered to be apolitical, and inappropriately so. It is indeed precisely this supposedly apolitical construction of the novels that is seen to reflect a problematic political attitude. Walser's strategy of portraying only what was part of the direct experience of the boy whose childhood and youth he tells is seen as something of a political ploy: 'The richness of description conceals the desire to find normality in a time that could never be considered normal'. ${ }^{109}$ In other words, Walser's nostalgic focus on the small town of Wasserburg excludes discussion of the system of National Socialism not only because the situation is seen through a boy's eyes, but because Walser seeks to focus on the normality of the past, thereby making it appear better, or more politically innocent, than it was. In Walser's case, this suspicion surely is not merely an outcome of reading his Ein springender Brunnen but rather takes into account his controversial criticism of how Germany deals with its past, not least in his acceptance speech for the 1998 Peace Prize of the German Book Trade.

\footnotetext{
107 Schmitz, On Their Own Terms, ch. 6.

108 Pfeifer, Der deutsche Kriegsroman, 82f.

109 Thomas Steinfeld, 'Der Wanderfotograf', Frankfurter Allgemeine Zeitung, 26/09/98, V.
} 
In this speech he objected to what he considers to be a 'ceaseless representation of our disgrace' and spoke of his desire to 'look away'. ${ }^{110}$ His speech was sharply criticised by the late Ignatz Bubis, then chairman of the Zentralrat der Juden in Deutschland (Central Council of the Jews in Germany), who called Walser's words 'intellectual arson'. ${ }^{111}$ The ensuing larger debate revolved around the role of memories of the Third Reich and the Holocaust in German politics. ${ }^{112}$ This debate might appear to be the obvious context within which Walser's literary work must be interpreted. ${ }^{113}$ Walser's interest in generating a more positive self-image of the German nation then becomes the lens through which his literary work is read. This approach is limited, however, because it would seem to miss the most interesting implications of Walser's attitude towards memory; for such a supposedly political reading of the novels fails to consider their political implications beyond assigning them a location on the left-right spectrum of politics. Therefore, I argue in the next section that reading novels politically (as distinct from interpreting them simply as part of the context of politics) must note the way in which they break up categories around which thinking about war, and indeed politics, is sometimes organised in a simplistic fashion.

\section{Beyond victim-perpetrator}

As we have seen, there is concern that dwelling on German experiences of the Second World War will only lead to the Germans reinventing themselves as victims, as Moeller argues they did in the $1950 \mathrm{~s},{ }^{114}$ and to the creation of a historically detached sense of German identity. This has to be avoided because the Germans are properly seen as perpetrators: they started the war and moreover brutally murdered millions of civilians. But, however clear this distinction may be in the abstract, its possibility is under threat by any consideration of the particular. The concern about war memories as inevitably making the

\footnotetext{
110 Martin Walser, Dankesrede. See also Walser's 'Das Gewissen ist nicht delegierbar', Frankfurter Allgemeine Zeitung, 12/10/98, 1.

111 'Was will Walser?', Süddeutsche Zeitung, 13/10/98, 15. See also 'Ignatz Bubis antwortet Martin Walser: Unterschwellig antisemitisch. Auszüge aus Rede zum 60. Jahrestag der Pogromnacht', Süddeutsche Zeitung, 10/11/98, 5.

112 For a commentary on the debate see Micha Brumlik, Hajo Funke and Lars Rensmann, Umkämpftes Vergessen. Walser-Debatte, Holocaust-Mahnmal und neuere deutsche Geschichtspolitik (Berlin: Das Arabische Buch, 2000).

113 See for example Schmitz, On Their Own Terms, ch. 6.

114 Moeller, War Stories.
} 
Germans think about themselves as victims betrays as much. Crucially, no one claims that their portrayal is incorrect, but Ledig's soldiers, vegetating in a hole and waiting to complete what is essentially a suicide mission, simply do not look like proper 'perpetrators'. There is some description of brutality against captured enemies in the novel, but nothing that we would quite term 'Wehrmacht atrocities'. ${ }^{115}$ However, the soldiers are not simply victims. War, as a senseless hell, confronts them with such force that such categories seem to have become meaningless. When a man has his limbs cut off before being run over by a tank and subsequently exploded, what does it mean to ask if he was a victim or a perpetrator? And does recognising that a classification as necessarily either victim or perpetrator will not add much in terms of understanding this particular individual's situation really amount to a denial or at least erasure of Wehrmacht atrocities?

In relation to memories of the Second World War in Grass's oeuvre, Roman Bucheli observes: 'It is painful wherever you look; you were perpetrator and victim in one; you felt shame for both. This synchronicity of guilt and disgrace, which cannot be offset against each other, represents a basic constant of his work'. ${ }^{116}$ Thus, in this view, it is not clear a priori that representing the war, even representing Germans as victims of the bombing of cities or expulsion from the east, supports the creation of a less problematic, historically detached German identity. The recognition that perpetrators and victims may not be safely separated from each other, and certainly not along national lines making all Germans purely perpetrators, is crucial for overcoming the impasse created by the requirement that appropriate war memories may in no sense render Germans as victims; for the claim that such clear categorisation is possible forces us to oscillate between two equally unsatisfactory and indeed unrealistic labels for German experience.

Whilst immediately after the war the Germans arguably saw themselves primarily as victims of both Nazism and the Allied war, they later had to recognise that they had been

115 For the debate about Wehrmacht atrocities see Heribert Prantl, ed., Wehrmachtsverbrechen. Eine deutsche Kontroverse (Hamburg: Hoffmann und Campe, 1997) and Gehorsam bis zum Mord? Der verschwiegene Krieg der deutschen Wehrmacht - Fakten, Analysen, Debatte, ZEITPunkte 3 (1995).

116 Roman Bucheli, 'Die verspätete Erinnerung', Neue Zürcher Zeitung, 09-10/02/02, 63. 
perpetrators. However, this classification then ruled out an acknowledgement of harrowing wartime experiences as part of official memory. In the 1990s, when interest in the expulsions and civilian experiences of wartime is finally again expressed, concern is raised about whether this means that the Germans are beginning to see themselves again as victims rather than perpetrators, simply because conceptually there is nowhere else to go. Perpetrator and victim are the only categories available, and they are mutually exclusive. However, an analytical approach to this past that must lead to the conclusion that a five-year old girl who died in the Hamburg fire storm has to be categorised as first and foremost a member of the perpetrator community seems, to put it mildly, of little use. It is precisely this shortcoming that makes it possible to turn the suffering of particular people into a myth of 'the Germans' as victims.

It is therefore crucial to recognise that the possibility of being 'perpetrator and victim in one' is at the heart of both the difficulty with war memories and, in fact, of political decisions relating to war today. This is not a position of moral equivalence, but it is one that faces the fact that the need to make difficult ethical decisions arises precisely when things are not clear. Therefore, if literature is able to raise doubts as to the mutual exclusivity and universal applicability of these categories, if it makes us understand that the intractable moral issue is precisely that people are rarely ever just one or the other but are often, to use the phrase again, 'perpetrator and victim in one', this is an important contribution to understanding war as an ethico-political problem. This does not make anything that happened less horrible or morally repulsive; it simply means that in war one is more likely to confront a mess in the face of which one has to make an ethical decision, rather than a neatly labelled multiple choice question where the answer is, at any rate, already given.

\section{Beyond good war-bad war}

Presumably, the worry about the appropriateness of memories is not so much about the past as it is about the future. There is rightly concern not only about not offending those who suffered most at the hands of Germans, but also about the political implications memories. This concern usually focuses on how Germans supposedly do or should feel about 
themselves as a nation. This debate seems to be always ongoing; the Historikerstreit, the controversy about Daniel Jonah Goldhagen's Hitler's Willing Executioners, the Walser-Bubis debate and the debate about the Holocaust memorial in Berlin have all revolved around these questions and others have commented at length on them. ${ }^{117}$ What is at issue in this article, however, is not how memories of the Second World War relate to how Germans seem to think about themselves, but to how they seem to think about war.

Though the rejection of war-'Nie wieder Krieg'-is seen as an important principle in postwar German politics, on closer examination it is actually a rejection of 'bad war' only. In the debates over uses of the military, Bundeswehr deployments abroad were from the start justified with reference to the Second World War. Crudely put, the Germans had to fight now, because their liberation from the Nazi regime had only been achieved through war and outside intervention. ${ }^{118}$ In other words, they had to be ready to do for others what the Allies had done for them: liberate them from oppression and war by violent means. This is, in my view, and I have argued this elsewhere, problematic per se as ethico-political reasoning is removed from the actual case at hand and instead understood in the context of Germany's relation to the past. ${ }^{119}$ Re-education in the Western sectors had been based on the shared responsibility of all Germans for Nazism and its crimes, and on the desire to ensure that the Germans would 'never again' wage war. ${ }^{120}$ Thus, 'war' was to be bad as such, and 'Nie wieder Krieg' together with 'never again dictatorship' came to be seen as fundamental to the

117 On the Historikerstreit see Forever under the Shadow of Hitler?, ed. Dan Diner; Ist der Nationalsozialismus Geschichte? Zu Historisierung und Historikerstreit (Frankfurt am Main: Fischer Taschenbuch Verlag, 1987); and Charles S. Maier, The Unmasterable Past. History, Holocaust, and German National Identity (Cambridge, MA and London: Harvard University Press, 1988). On the controversy around Goldhagen's book see Robert R. Shandley, ed., Unwilling Germans? The Goldhagen debate (Minneapolis: Minnesota Press, 1998) and Norman G. Finkelstein and Ruth Bettina Birn, A nation on trial: the Goldhagen thesis and historical truth (New York: Henry Holt, 1998). On the Walser-Bubis debate see Frank Schirrmacher, ed., Die WalserBubis-Debatte: eine Dokumentation (Frankfurt am Main: Suhrkamp, 1999) and Brumlik/Funke/Rensmann, Umkämpftes Vergessen. On the debate about the Holocaust memorial see Caroline Wiedmer, The Claims of Memory. Representations of the Holocaust in Contemporary France and Germany (Ithaca and London: Cornell University Press, 1999) and Jenny Edkins, Trauma and the Memory of Politics (Cambridge: Cambridge University Press, 2003), 132-134.

118 Klaus Kinkel (foreign minister) in Deutscher Bundestag, Plenarprotokoll, 13/48, 30/06/95, 3957.

119 See Zehfuss, Constructivism and International Relations.

120 Susan L. Carruthers, 'Compulsory Viewing: Concentration Camp Film and German Reeducation', Millennium: Journal of International Studies 3 (2001): 735. 
Basic Law, ${ }^{121}$ and hence the new (West) German state. Crucially however, the evilness of the German war is then also the background against which the goodness of the Allied war can be secured. ${ }^{122}$ The Allies liberated the Germans and thereby enabled the new democratic beginning. ${ }^{123}$ The Allied war was therefore definitely good. In this argument, war is constituted as a circumscribable entity which may be ethically judged in an abstract way.

Re-education, and later (West) German self-representation, involved what Derrida might call an overturning. ${ }^{124}$ The soldiers' role, which had been seen in terms of an honourable defence of the fatherland, came to be seen as indirect support of, and in some cases direct involvement with, Nazi crimes. This message is reinforced by critical examinations of the role of the Wehrmacht itself, such as the exhibition of the Hamburger Institut für Sozialforschung. ${ }^{125}$ It is useful to turn here briefly to Derrida's exploration of how oppositions (e.g. male/female or nature/nurture) - what he calls dichotomies - structure our thinking. Though both terms may appear to be on an equal footing, each pair is actually dominated by the first term. For example, on the whole we tend to value supposedly male qualities such as rationality more highly than those taken to be female qualities such as sensitivity. A response to this may be to try to think in a way that overturns this hierarchy. However, whilst this is a useful first step, it leaves in place the structure of the system: we are still thinking in terms of gender difference. The overturning on its own is not enough because the hierarchy will reassert itself. A second step is necessary, namely to achieve a displacement, in other words, to begin thinking in terms of concepts that are not part of the previous system of thought. ${ }^{126}$

In our case, by devaluing German soldiers' activity merely because they were on the wrong side and hence fighting a 'bad war', the possibility of fighting a 'good war' remained wide open, was indeed-through the possibility of opposing the Allied war to the German

\footnotetext{
121 Helmut Kohl (Chancellor) in Deutscher Bundestag, Plenarprotokoll, 11/228, 04/10/90, 18019.

122 Carruthers, 'Compulsory Viewing', 733.

123 Klaus Kinkel (Foreign Minister) in Deutscher Bundestag, Plenarprotokoll, 13/48, 30/06/95, 3957.

124 Derrida, Jacques, Positions, trans. Alan Bass (London: The Athlone Press, 1987), 41.

125 See the exhibition catalogue. Hamburger Institut für Sozialforschung, ed., Vernichtungskrieg.

Verbrechen der Wehrmacht 1941 bis 1944 (Hamburg: Hamburger Edition, 1996).

126 See Derrida, Positions, $42 f$.
} 
war-reinforced. Thus, after the end of the Cold War, the argument that military activity approved of by NATO allies was good and hence required of the Germans, ${ }^{127}$ led to an acceptance by the German government, and increasingly also the German public, of the necessity and ethical value of participation in missions such as Operation Allied Force. Despite attempts, at least at first, to construe Bundeswehr missions as 'not war', ${ }^{128}$ this ultimately meant that the 'Nie wieder Krieg' principle was eroded and reinterpreted. The recent dramatic rejection of any participation in the war against Iraq might, on the surface, seem to run counter to this trend. However, it is worth noting that whilst the German stance involved taking a position against the United States and against the proposed war, this was by no means a particularly 'German' position. More importantly, it clearly follows the trend of previous debates about military involvement abroad in that it was a refusal in the abstract, one that did not particularly address the problematic of Iraq.

How does any of this relate to what has been argued here about representations of war in novels? Bundeswehr soldiers deployed to Bosnia were, in the political debate, likened to the heroic Allied liberators of the Second World War. ${ }^{129}$ This analogy is problematic for a range of reasons, but in particular because it trivialises the ethico-political issue of the concrete Bundeswehr deployment and moves the debate to the abstract and indeed to the past. The issue is not one of dealing with current political problems in Bosnia, Kosovo or Afghanistan, but one of demonstrating that the Germans have overcome their past. Crucially, this analogy is so appealing because the Allied contribution to the Second World War is recognised as a 'good war'-the war that brought democracy to the FRG-and the adverse consequences of that war are often blanked out. It might disturb Germans to think that some of their ancestors did not die a painless death as a result of a shot in the chest but might have rather been blown up alive or chopped into parts by machine gun fire; but what might confuse them even more about the Federal Republic's military involvement abroad is

\footnotetext{
127 Zehfuss, Constructivism in International Relations, esp. ch. 2.

128 Rather they were referred to as 'peace-making measures', 'coping with a crisis situation', the 'last resort' or even 'energetic prevention'. See 'Einsatz ins Ungewisse', DER SPIEGEL, 5/49, 30/01/95, 71.

129 Zehfuss, Constructivism in International Relations, 136.
} 
the idea that that is precisely what soldiers would be doing to others in their name. In other words, the supposedly apolitical portrayal of war as a physical and moral mess-for example in Ledig's Die Stalinorge/-undermines the possibility of instrumentalising the Second World War to present people with an abstract and supposedly ethical choice about war today. Given the 'clean' representation of war on television today, this might be more important than it would at first appear.

Because thinking about war after 1945 involved an overturning but no displacement, it was possible for the hierarchy to flip back, and for the Germans to take their place again on the side of 'good war'. The confrontation with concrete war memories, far from necessarily leading to a moral relativism that counts German bodies against those killed by Germans, helps us to leave behind a system of thought that turns decisions about war into a choice between black and white, good war and bad war, and instead recognise the mess that calls for a responsible decision. This is crucial because in the post-Cold War, and certainly in the post-September 11 , world it has increasingly become necessary to address the question of war, also for the Germans. Derrida insists that ethico-political decisions are called for precisely when things are not clear: 'When the path is clear and given, when a certain knowledge opens up the way in advance, the decision is already made, it might as well be said that there is none to make: irresponsibly, and in good conscience, one simply applies or implements a program'. ${ }^{130}$

Literature is significant in this context as it may undermine the black-and-white choice we are presented with in relation to war by reminding us that, as Bucheli says of Grass's representations of the Second World War, 'you were perpetrator and victim in one'. ${ }^{131}$ Ledig's Die Stalinorgel equally undermines neat distinctions between 'good' and 'bad' war, perpetrators and victims. Novels can, in other words, be interesting because they are able to provide narratives that destabilise the unity of the signifier 'war'. Ledig's depiction of the

\footnotetext{
130 See, for example, Derrida, Other Heading, 41, emphasis in original.

131 Roman Bucheli, 'Die verspätete Erinnerung', Neue Zürcher Zeitung, 09-10/02/02, 63. On a similar point, see also Jenny Edkins, 'Authenticity and Memory at Dachau', Cultural Values 5 (2001): 418 .
} 
battle over a hill close to Leningrad may support the notion that war is bad as such, in that war is represented as a senseless hell, but by linking this judgement to the specificity of the particular battle it works against the overturning we see in current politics. Walser's reflections on the past and the present undermine the idea of the past as a repository of unchanging experiences from which we can draw lessons for the present even more fundamentally. Federal Chancellor Helmut Kohl wanted to use the past as a 'compass' for the future. ${ }^{132}$ However, if the past changes with the present as Walser suggests, the compass is not an objective, outside tool that simply shows us the way. Thus the 'truth of fiction' raises fundamental questions about ethics.

\section{The truth of fiction}

German literature finds itself in a double bind highlighting that truth and ethics are inextricably linked. On the one hand is the complaint, championed by Sebald, that German literature has failed to confront the history of the war which is so crucial to Germany. ${ }^{133}$ On the other hand is the related charge made whenever literature does engage in this past that the representations it produces are inappropriate. In Language of Silence, a detailed study of West German literature, Schlant rejects any number of novels about the Nazi period for their failure to appropriately represent Jewish life and the Holocaust, and a few for their failure to depict the crimes of German soldiers. ${ }^{134}$ In the recent debates about German war memories, it is even alleged that the traditionally leftist writer Grass, through focusing on German suffering in his latest novella Im Krebsgang (Crabwalk), becomes part of the 'transformation of the society of perpetrators into one of victims'. ${ }^{135}$

Sebald's argument that the air war against Germany has not been dealt with by German authors rests not on an actual lack of depiction of these events, or at least not entirely, but on

Deutscher Bundestag, Plenarprotokoll, 04/10/90, 11/228, 18019.

Sebald, Luftkrieg und Literatur.

Schlant, Language Silence, esp. 30.

See Volker Hage, 'Unter Generalverdacht', DER SPIEGEL, 15, 08/04/02, 178. Hage is critical of this view. 
his judgement that the representations are 'questionable'. ${ }^{136}$ For example, he castigates Arno Schmidt's Aus dem Leben eines Faun (From the Life of a Faun) for 'dynamic language actionism, with which Schmidt produces the spectacle of an air raid'. ${ }^{137}$ He objects to the 'demonstrative avant-gardism' of the depiction. ${ }^{138}$ It is clear-though he never explicates quite what, if anything, would be appropriate-that these objections, although sometimes phrased as a concern about 'authenticity', ${ }^{139}$ reflect a concern with the ethicality of the representations. In other words, the problem in representing German war experiences is not so much truth—no one disputes the 'truth' of portrayals that explore Germans' suffering—but ethics; that is, whether such portrayals are ethical. The problem is, in Richard Kearney's words, that '[e]very narrative bears some evaluative charge regarding the events narrated'. ${ }^{140}$ In our context this means that the evilness of Germans' conduct, and our grasp of it, must not be diminished through a representation of Germans' (even if different Germans') suffering.

Kearney stresses the notion of 'narrative truth' when it comes to matters of historical trauma, ${ }^{141}$ whilst Sebald speaks of the necessity of 'an artificial view' as eye witnesses would invariably have been impaired in their capacity to think and feel. ${ }^{142}$ Thus, fictional representation is, or so the argument goes, both bound by truth and necessary to telling truth in the first place. Indeed, Lothar-Günther Buchheim's war novel Die Festung (The Fortress) is advertised on its back cover as 'more authentic than any factual report'. ${ }^{143}$ We might be turning to fiction to avoid something that is too much, the closure imposed by historical narrative. Hayden White has suggested that the 'value attached to narrativity in the representation of real events arises out of a desire to have real events display the coherence,

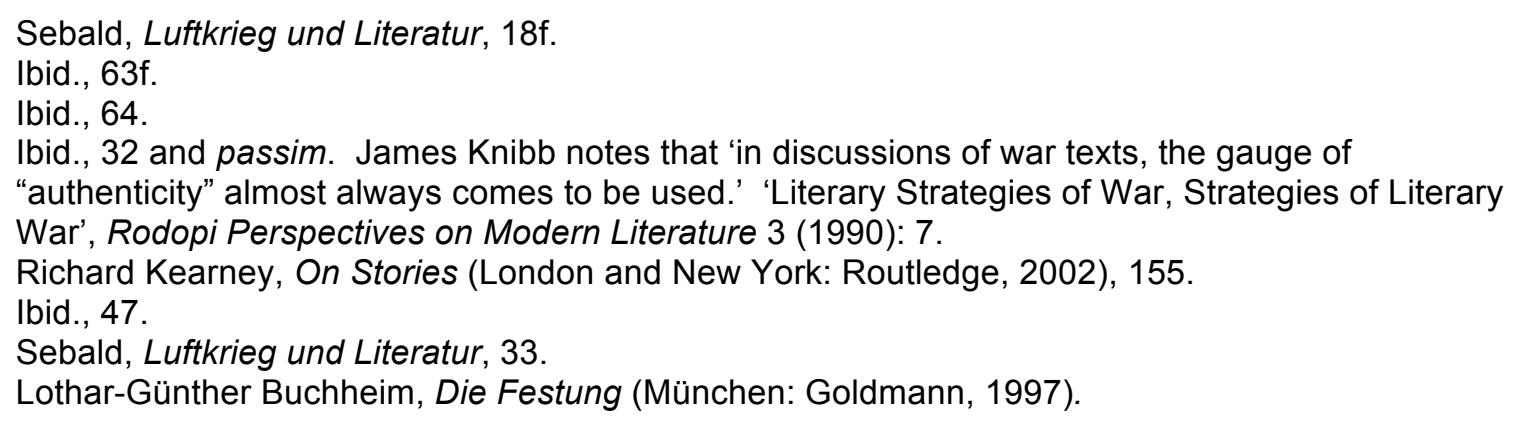


integrity, fullness, and closure of an image of life that is and can only be imaginary'. ${ }^{144}$ Fictional accounts, in contrast, may avoid such closure, which would at any rate be 'fictitious' in the sense that the meaning given to events would not have been available to those involved at the time. Ledig's ruptured plot is an example of resisting 'meaning' that can only ever be imposed ex post facto. On the other hand, we might need to turn to fiction to represent an excess, something that goes beyond what historical narrative may capture, such as emotions but also, significantly, the failure of different narratives to neatly add up into 'the whole story'. Ledig and Walser are both motivated by telling what was and the reading public is again interested in literary representations of war: there is a turn to fiction to render and read truth.

'Truth' may appear to be an awkward category with which to approach fiction. Sebald's presumption that he may judge the appropriateness-whatever he may mean by this precisely - of any fictionalisation is in tension not only with any notion of poetic licence but also with the idea of literature as counter-memory. It is precisely judgements such as Sebald's that Walser's musings on the past as present render problematic. As discussed earlier, Walser is worried about the increasing standardisation of how we deal with the past. He rejects the notion of a 'past which is completely reconstructed [erschlossen], investigated, sanitised, sanctioned, totally fit for the present. Ethically and politically corrected through and through. ${ }^{145}$ Rather we must confront the issue that the past may have been such that we do not find it acceptable now, and that we may never represent it without already introducing the present. He asks whether there is 'more past or more present in being over'. ${ }^{146}$ Thus what we may know about the 'truth' of the past not only changes over time as we do; it is indeed also not separate from ethics. Objections against representations of the Second World War rarely concern simply issues of truth. At issue are rather ethical considerations. Thus, Ledig's depiction of the eastern front is not seen as in some way incorrect. It is not the

\footnotetext{
144 Hayden White, The Content of the Form. Narrative Discourse and Historical Representation (Baltimore and London: The Johns Hopkins University Press, 1987).

145 Walser, Ein springender Brunnen, 282.

146 Walser, Ein springender Brunnen, 15.
} 
facticity of the account that is disputed, but its contextualisation or rather, as the critics would have it, the lack thereof. May the hardships German soldiers experienced at the front be narrated without giving the whole context of the atrocities committed in the name of the Third Reich? The concern here, although possibly presented as one about 'the full truth', is about ethics. This is where Walser's worry about an ethically corrected memory comes in. But the implications of his intervention are not straightforward as it does not promote simply the right to speak out about how things were, whether or not it fits in with approved notions of an ethical attitude towards the past; for Walser rejects the notion that there is a true memory which we could recover: he argues for his right to represent his memory-which he at the same time points out does not and cannot appeal to an unchanging truth that we might seek to recover. ${ }^{147}$

\section{Conclusion}

Discussions about the usage of the military instrument in Germany, but also elsewhere, often refer back to the Second World War. ${ }^{148}$ They do so in a way that assumes the ready availability of categories within which to contextualise an abstract ethical choice. This article turned to novels to engage with detailed representations of war, establishing readings of fiction as an integral part of engaging with the 'truth' about war. Using the example of Ledig's Die Stalinorgel it demonstrated not only that clear distinctions between, for example, victim and perpetrator are always under threat from the particular, but also that literary representations are able to negotiate the terrain of war's excess of horror, that is invariably obscured when a meaning is imposed to make possible a coherent 'factual' account. In other words, the truth of fiction goes 'beyond' what is possible in the media that are traditionally part of the study of war. Inevitably, and crucially, truth is not secure. Both Ledig's direct rendition of the confusion and mayhem of combat and Walser's distanced reflection on how

\footnotetext{
147 Note that this would seem to be rather in tension with the simplistic political views in the context of which his work is often read.

148 Note, for example, the comparison of the attacks of September 11, 2001 with Pearl Harbor in Secretary Donald Rumsfeld in United States Department of Defense, Testimony of U.S. Secretary of Defense Donald Rumsfeld before the House Armed Services Committee regarding Iraq (Transcript), 18/09/02.
} 
the present interferes with the past whenever we remember draw attention to the impossibility of simply recovering or representing 'the truth' about war. It is not a matter of simply having to acquire more information: there will always be an excess, competing narratives will never provide simply the truth. To put this differently, it is not that fiction finally provides us with the truth about war, but that it provides us with food for thought both about the desire to know and, ultimately, the impossibility of fully knowing war.

This is adamantly not to say that we should not seek as much knowledge as possible, but merely that knowledge does not, in relation to war, provide us with a secure way forward. As Derrida notes, 'Not that it is necessary not to know. On the contrary, it is necessary to know the most and the best possible, but between the widest, the most refined, the most necessary knowledge, and the responsible decision, an abyss remains, and must remain'. ${ }^{149}$ The security of knowledge about war was undermined by a close look which revealed that the categorisations and clear dichotomies in arguments about war become problematic as soon as we engage with the particular. This invariably leads to a loss of (moral) certainty, something that might appear threatening to some. From a Derridean angle, however, this encounter with the aporia, the non-way, is, in contrast, an opportunity that makes ethicopolitical decisioning possible. Reading novels about war politically is, as a consequence, a significant way in which we may approach the ethico-political question of war.

We cannot simply learn from the past and be certain about what we should do in relation to war today. It is, however, precisely by recognising this that we may avoid being lulled into a false sense of security: a belief that the application of abstract categories and rules will ensure that we are acting ethically. The aporia of war lies not only in the tragedy of violent death but in the inevitability of decisions that will never be fully just, that are marked by the 'ordeal of the undecidable'. It is imperative, if we are interested in responsibility and ethicality at all, that we acknowledge the ethical tension and the failure of knowledge in the face of it. Writing war-in so far as it keeps open and enables us to reflect on this tension and the

149 Jacques Derrida, On Cosmopolitanism and Forgiveness, trans. Mark Dooley and Michael Hughes (London and New York: Routledge, 2001), 54. 
resulting uncertainty—-therefore represents a crucial contribution to avoiding the temptation of 'good conscience' that comes with a moral certainty about the 'right' decision, a certainty that can only ever be misplaced in relation to the ethico-political problem of war. 